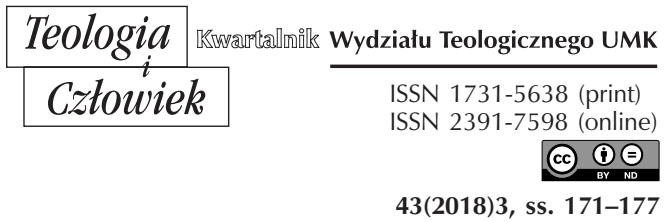

KS. KAZIMIERZ SKOCZYLAS WYDZIAŁ TEOLOGICZNY UNIWERSYTETU MIKOŁAJA KOPERNIKA W TORUNIU KSKOCZYLAS@DIECEZJA.WLOCLAWSKA.PL ORCID: 0000-0002-3287-5317

\title{
SPRAWOZDANIE Z KONGRESU KATOLICKICH PEDAGOGÓW RELIGII I KATECHETYKÓW OBSZARU JĘZYKA NIEMIECKIEGO W AUGSBURGU 2018 ROKU
}

DOI: http://dx.doi.org/10.12775/TiCz.2018.033

Kongres pedagogów religii i katechetyków odbywał się w dniach 13-16 września 2018 r. w domu rekolekcyjnym św. Pawła w Leitershofen w Augsburgu. Uczestniczyli w nim katoliccy pedagodzy religii i katechetycy z obszaru języka niemieckiego, czyli z Niemiec, z Austrii oraz Szwajcarii. Brali w nim także udział goście z Czech, Chorwacji, Polski i Ukrainy.

Jako hasło przewodnie tegorocznego zgromadzenia wybrano problematykę prawdy: „Gra o prawdę. Religijne kształcenie w czasie postfaktycznym” Wyrażenie postfaktisch w języku niemieckim przejęto z języka angielskiego. W ten sposób przetłumaczono wyrażenie post-truth co często w języku polskim tłumaczy się jako post-prawdę. Słowo to stało się słowem roku w Anglii i Niemczech po wydarzeniach związanych z Brexitem i kampanią prezydencką Trampa w 2016 roku. Także Angela Merkel użyła tego wyrażenia by podkreślić, że żyjemy w czasie postfaktycznym. To określenie stało się podstawą do tworzenia nowych wyrażeń. Jednym $\mathrm{z}$ nich jest postfaktyczna polityka (por. wikipedia.de). Jak zauważa niemiecka Wikipedia „The Economist” napisał we wrześniu 2016 r., ze celowe 
kłamstwo polityczne nie jest centralnym punktem polityki post factum. Użycie politycznego kłamstwa oznacza, że istnieje prawda i że zna ją kłamca. Dowód, konsekwencja i nauka są siłą polityczną w normalnym dyskursie politycznym. Tymczasem kategorie te przestają interesować coraz większą liczbę osób w publicznym dyskursie. Nastąpiła zmiana w kierunku rozumienia polityki, w której uczucia przebijają fakty. Co więcej, jeśli odległość pomiędzy tym, co wydaje się prawdziwe, a tym, co jest prawdą, staje się zbyt duża, odległość ta często jest wyjaśniana przez teorię spiskową ze względu na prostotę. W niektórych przypadkach konfrontacja $\mathrm{z}$ faktami paradoksalnie prowadzi do tego, że nawet przylgnięcie do błędnego oświadczenia było nawet zachętą" (Postfaktische Politik, wikipedia.de). W tym sposobie mówienia w wypowiedzi na pierwszym planie nie chodzi o przekazanie prawdy, ale przede wszystkim o to, aby wypowiedzi o silnie kontekście emocjonalnym pozwoliły pozyskać słuchacza. Aby zyskać aprobatę słuchacza, nadawca wypowiedzi kieruje się często kłamstwem czy półprawdą. Stąd takie postępowanie nazywa się kreowaniem rzeczywistości.

Ten nowy sposób podejścia do prawdy był inspiracją, jak zauważyła we wprowadzeniu przewodnicząca AKRK prof. Claudia Gärtner, do pojęcia problematyki jak może dokonywać się przekaz prawdy religijnej w kontekście tak silnie naznaczonym postfaktycznym stylem wypowiedzi bardzo często obecnym w życiu publicznym. Jakie znaczenie może to mieć dla przekazu prawdy religijnej.

W pierwszym dniu spotkania wprowadzeniem w problematykę były cztery krótkie wypowiedzi odnoszące się do literatury (dr Johannes Heger, Freiburg), sztuki (dr Viera Pirker, Wien), mediów (prof. Bernd Trocholepczy, Frankfurt) i polityki (prof. dr Judith Konemann, Munster) a potem nastąpił wykład na temat prawdy w teologii, który przedstawił specjalista z zakresu teologii dogmatycznej prof. dr Roman A. Siebenrock z Insbrucka. W swoim wystąpieniu mówił, jak odnosi się dziś teologia do pytania o prawdę. Swoją wypowiedź przedstawił w trzech etapach: najpierw mówił o prawdzie w znakach czasu, potem o filozoficznym poznaniu a na końcu o zarysie prawdy teologicznej. W pierwszej części uwypuklił spostrzeganie prawdy ad intra i ad extra. Ad intra z prawdą wiąże się pytanie jak i w jakim kontekście oczekuje się prawdy w teologii. Tradycyjnie spodziewamy się, że prawda jest podstawą modrości wiary 
i kościelnego autorytetu. W odniesieniu do płaszczyzny zewnętrznej wyraża się to w pytaniu gdzie i jak jest prawda tematem wybuchowym. Potem wskazał na oczekiwania prawdy w zakresie wiary. Płaszczyznami, w których oczekuje się prawdy są; własne życie, społeczność, polityka, płaszczyzna rzeczywistości transcendentnej, czyli wyobrażenie o Bogu i wypełnienie się całej rzeczywistości, prawda jako wezwanie do przekroczenia siebie, zasadnicze rozstrzygnięcia dotyczące prawdy w apostolskich czasach jako wyzwanie dla filozofii. Następnie podkreślił zbawcze działanie prawd wiary, wskazując, że wiara jest odpowiedzią zawartą w objawieniu, że wiara jest istotnym elementem rozumienia człowieka, że wiara jest zarazem doświadczeniem i wiedzą. Dalszą część wykładu poświęcił filozoficznemu rozumieniu prawdy. Pokazał różne aspekty rozumienia prawdy w filozofii. Doprowadziło go to do wniosku, że coś, co jest prawdziwe ocenia się jako wyobrażenie celu i służy jako krytyczne kryterium w zderzeniu różnych opinii. Ostatnia część dotyczyła poznania prawdy w teologii. Takie teorie prawdy służą jako krytyczne sprawdzenie własnych i wspólnotowych przekonań w relacji do innych z zamiarem eschatologicznego pojednania się świata i historii po to, aby służyć historii i żyć w teraźniejszości. Powołał się na model prawdy Newmana, jako wspólnotową i osobową drogę wzrastającego zaufania do wiary dającej świadomość jedności i świadomość siebie oraz otwarcia na historię; ale też jako zachowanie idei chrześcijańskich w historii. Zauważył też, że prawda w inny sposób jest poszukiwana w teologii negatywnej i apofatycznej. Teologia negatywna akcentuje, że nic o Bogu powiedzieć nie można. Teologia apofatyczna otwiera przestrzeń dla prawdy, w której stworzenie może zyskać nowe aspekty prawdy.

Drugi dzień poświęcony był polom, na których poszukuje się prawdy. Pierwszy wykład przedstawiła dr Viera Pirker z Wiednia. Podjęła temat tożsamości, jej struktury i relacji do religijności. Najpierw autorka zauważyła, że istnieje tożsamość wspólnotowa. Na jej umocnienie ukierunkowana bywa polityka tożsamości. Przywołała tu działania przewodniczącego bawarskiej CSU Markusa Södera, który dla uwypuklenia chrześcijańskiego charakteru tożsamości mieszkańców Bawarii zarządził, aby w każdym urzędzie na terenie Bawarii znalazł się krzyż. Podkreśliła, że te działania nie znalazły akceptacji zarówno biskupów katolickich Bawarii jak też różnych grup społecznych. Budowanie tożsamości jest 
pojęciem wieloznacznym. Może oznaczać ideologizację społecznej i politycznej praktyki. Tożsamość może być rozumiana także jako działanie, które pomaga określić siebie czy też można ją rozumieć jako kulturalną tożsamość dążącą do uwypuklenia w kulturze tych aspektów z powodu których czujemy się przynależni do określonej grupy.

Viera Pirker podkreśliła także, że istnieje też tożsamość indywidualna. Określana jest najpierw dość ogólnie, jako te cechy zewnętrzne zapisane np. w dowodzie tożsamości (np. wzrost, kolor oczu), bądź jako role społeczne do których jesteśmy wdrażani czy wreszcie głęboka przynależność. Istotne znaczenie dla zrozumienia tożsamości ma tożsamość psychologiczna, która pozwala odpowiedzieć, kim jestem i jak stałem się osoba. To dość dokładnie opisuje Erikson. Wskazuje on na 8 etapów dojrzewania tożsamości. Według teorii Eriksona, rozwój jednostki przebiega stadiami. On wyróżnił osiem stadiów tego rozwoju. Pierwsze cztery stadia występują $\mathrm{w}$ niemowlęctwie i dzieciństwie, piąte stadium w okresie dojrzewania, a ostatnie trzy w wieku dojrzałym ze starością włącznie. W swych pracach Eriksson kładzie szczególny nacisk na okres dojrzewania, ponieważ wówczas następuje przejście od dzieciństwa do wieku dojrzałego. To, co dzieje się w tym stadium, ma ogromne znaczenie dla osobowości człowieka dorosłego. Należy zwrócić uwagę, że stadia nie następują po sobie według jakiegoś ściśle określonego rozkładu czasowego. Erikson sądzi, że każde dziecko ma własny „rozkład”, a zatem dokładne określanie czasu trwania każdego stadium, byłoby mylące. Ponadto nie jest tak, że dane stadium mija bez śladu. Przeciwnie, każde stadium przyczynia się do ukształtowania całej osobowości. Erikson obserwuje osobowość przede wszystkim w aspekcie jej ontogenetycznego rozwoju i zwraca uwagę na to, że już doświadczenia z wczesnego dzieciństwa są ważne ze względu na tożsamość. Owe dziecięce doświadczenia, w których dużą rolę odgrywa przede wszystkim identyfikowanie się z dorosłym, trzeba postrzegać jedynie jako przygotowanie do tworzenia własnej tożsamości. Zdaniem Eriksona czynnikiem wewnętrznym aktywizującym proces kształtowania tożsamości jest ego w swych aspektach świadomych i nieświadomych. W tym stadium ego ma zdolność selekcjonowania i integrowania talentów, uzdolnień i umiejętności w procesach identyfikacji z podobnie myślącymi ludźmi i adaptacji do środowiska społecznego oraz zdolności utrzymywania swych środków obrony przeciw zagrożeniom 
i lękowi, uczy się bowiem decydować, jakie impulsy, potrzeby i role są najbardziej potrzebne i efektywne. Wszystkie te cechy wyselekcjonowane przez ego są też prze nie łączone i integrowane, tworząc tożsamość psychospołeczną danej osoby.

Autorka, odwołując się do teorii Erika Eriksona, zauważyła, że dziś wiele osób buduje swoją tożsamość w sposób bardzo zewnętrzny, np. przez zamieszczanie zdjęć selfie na Facebooku czy przez różne filmy zamieszczane na YouTube opisujące ich doświadczenia prowadzące do pogłębienia tożsamości.

Odwołując się do wiedzy psychologicznej podkreśliła, że tożsamość tworzy się na trzech płaszczyznach czyli samookreślenia, płaszczyźnie identyczności (płeć, rodzina, praca, wartości, kultura, światopogląd, polityka) oraz metatożsamości. Czynnikiem wyzwalającym tworzenie się tożsamości są działania i pełnione role szczególnie w okresie dorastania we wszystkich wspomnianych płaszczyznach identyczności. Odnosząc to do kształtowania się tożsamości religijnej zaakcentowała wielką wartość zachowań religijnych osób, przede wszystkich przykładów zachowań religijnych czerpanych z najbliższego otoczenia. Drugim czynnikiem odgrywającym wielką rolę $\mathrm{w}$ kształtowaniu się tożsamości religijnej są instytucje kościelne i włączanie w ich działalność młodego pokolenia.

Profesor Dagmar Hoffmann z Siegen, specjalistka z zakresu mediów społecznościowych, pojęła temat szukania, znajdowania i sprawdzania prawdy w sieci. Wychodząc od stwierdzenia, że media mają coraz większe znaczenie w życiu pojedynczych osób odniosła się do mitu emancypacyjnego mediów. W mediach najbardziej są obecni, jako przekazujący informację, przede wszystkim dziennikarze, politycy i naukowcy. Największą rolę odgrywają dziennikarze, bo oni selekcjonują wiadomości i decydują, co i według jakiego klucza zostanie upublicznione. Dziś rośnie krytyka mediów, bo one się centralizują i narzucają swój punkt widzenia. W mediach społecznościowych każdy odbiorca może też być nadawcą. Dzięki możliwości interakcji szybko można poznać relacje zwrotne na temat przekazywanych informacji. Nowym zjawiskiem w tego tupu mediach jest zjawisko produkcji medialnej, która staje się procesem uczenia. Media te gromadzą liczne społeczności, służą wymianie informacji, ale też używają swojej siły w celu upowszechniania opinii. Tematy szeroko upowszechniane przez media społecznościowe i tam zyskujące wielką 
popularność stają się tematami podejmowanymi przez media publiczne Dobrym tego przykładem są Twitter, Instagram, Facebook czy YouTube. Tematy, które tam zyskały popularność trafiają do prasy bądź radia czy telewizji. Najliczniejszą grupę zaangażowanych w te media stanowią osoby między trzydziestym a czterdziestym rokiem życia. Mimo tak powszechnej obecności mediów społecznościowych w życiu młodych charakterystycznym jest, że młodzież szuka odpowiedzi na ważne pytania najpierw w bezpośrednim kontakcie z osobami z kręgu rodzinnego, a dopiero potem $\mathrm{w}$ mediach.

Po południu drugiego dnia przewidziano prace $\mathrm{w}$ grupach. Pierwsza grupa zajęła się prawdą i fałszem w lekcji religii, druga podjęła temat: Jezus Chrystus jako prawda chrześcijańskiej wiary; trzecia - czy prawda jest pytaniem dla katechezy parafialnej, a ostatnia grupa zajęła się problemem: otwarte fora jako miejsca dyskusji na tematy religijne.

Wieczorem odbyło się walne zebranie stowarzyszenia, na którym wybrano nowy zarząd. Jej przewodniczącym wybrano prof. Angelę Kaupp. Następny dzień dotyczył miejsc, w których jest obecna pedagogika religii. Przed południem odbył się Workshop. Każdy Workshop dotyczył innego aspektu rzeczywistości religijnej. Prof. Monika Scheidler z Drezna $\mathrm{w}$ pierwszym $\mathrm{z}$ nich skupiła się na problemie silnej konfrontacji wśród katolików w Niemczech wschodnich w stosunku do uchodźców. Drugi Workshop pod kierunkiem prof. Martiny Kraml i prof. Zekrija Sejdini skoncentrowany był na międzyreligijnej formacji: pomiędzy ograniczoną świadomością a oczekiwaniem poznania prawdy. Trzeci dotyczył adekwatnej teorii dla międzyreligijnego procesu uczenia. Przewodniczyła mu prof. Sabine Pemsel-Maier. Czwarty prowadzony przez prof. Georga Langenhorsta z Augsburga dotyczył przekazywania prawdy religijnej $\mathrm{w}$ poetyckiej formie spotykanej w psalmach czy liturgii Kościoła. Każdy uczestnik mógł wybrać dwa problemy z zaproponowanych form i wziąć w nich udział.

Sesja popołudniowa poświęcona była poznaniu i ocenie posterów przygotowanych przez doktorantów z różnych ośrodków naukowych Niemiec. Najlepszy poster został nagrodzony nagrodą publiczności. Potem nastąpiło podsumowanie i przedstawienie wniosków z uczestnictwa w Workshops. Wieczorem świętowano pięćdziesięciolecie istnienia AKRK. 
W niedzielę prof. Thorsten Knauth z Duisburg-Essen przedstawił wykład dotyczący problematyki prawdy w dialogicznej pedagogice religijnej. Drugi wykład przedstawiony przez prof. Edan Aslan z Wiednia uwypuklił, że w dialogu własne rozumienie prawdy zostaje ubogacone przez uczestników dialogu. Potem dokonano podsumowania kongresu a po obiedzie zorganizowano wspólne posiedzenie dawnego i nowego zarządu stowarzyszenia AKRK. 